\title{
Communication \\ Potential Use of Colored LED Lights to Increase the Production of Bioactive Metabolites Hedyotis corymbosa (L.) Lam
}

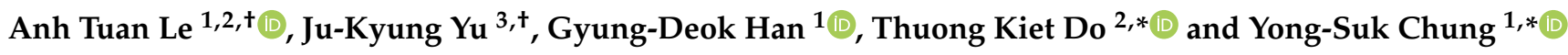 \\ 1 Department of Plant Resources and Environment, Jeju National University, Jeju 63243, Korea; \\ anhtuan.sinhhoc@gmail.com (A.T.L.); hangds@jejunu.ac.kr (G.-D.H.) \\ 2 Department of Plant Physiology, Faculty of Biology—Biotechnology, University of Sciences, VNU-HCM, \\ Ho Chi Minh 70000, Vietnam \\ 3 Seeds Research, Syngenta Crop Protection LLC, Research Triangle Park, 9 Davis Dr, Durham, NC 27703, USA; \\ ju-kyung.yu@syngenta.com \\ * Correspondence: dtkiet@hcmus.edu.vn (T.K.D.); yschung@jejunu.ac.kr (Y.-S.C.) \\ + These authors also contributed equally to this work.
}

Citation: Le, A.T.; Yu, J.-K.; Han, G.-D.; Do, T.K.; Chung, Y.-S. Potential Use of Colored LED Lights to Increase the Production of Bioactive Metabolites Hedyotis corymbosa (L.) Lam. Plants 2022, 11, 225. https:// doi.org/10.3390/plants11020225

Academic Editor: Agnieszka Klimek-Kopyra

Received: 31 December 2021

Accepted: 14 January 2022

Published: 15 January 2022

Publisher's Note: MDPI stays neutral with regard to jurisdictional claims in published maps and institutional affiliations.

Copyright: (C) 2022 by the authors. Licensee MDPI, Basel, Switzerland. This article is an open access article distributed under the terms and conditions of the Creative Commons Attribution (CC BY) license (https:// creativecommons.org/licenses/by/ $4.0 /)$.

\begin{abstract}
Hedyotis corymbosa (L.) Lam is a wild herb that is used in traditional Indian, Chinese and African medicine. Light-emitting diode (LED) technology is paving the way to enhance crop production and inducing targeted photomorphogenic, biochemical, or physiological responses in plants. This study examines the efficiency of $H$. corymbosa (L.) Lam production under blue $450 \mathrm{~nm}$ and red $660 \mathrm{~nm}$ LED lights for overall plant growth, photosynthetic characteristics, and the contents of metabolite compounds. Our research showed that blue LED lights provided a positive effect on enhancing plant growth and overall biomass. In addition, blue LED lights are more effective in controlling the production of sucrose, starch, total phenolic compounds, and total flavonoid compared to red LED lights. However, blue and red LED lights played essential but different roles in photosynthetic characteristics. Our results showed the potential of colored LED light applications in improving farming methods and increasing metabolite production in herbs.
\end{abstract}

Keywords: Hedyotis corymbosa (L.); light-emitting diode (LED); plant growth; photosynthesis; metabolites production

\section{Introduction}

Hedyotis corymbosa (L.) Lam, a synonym of Oldenlandia corymbosa (L.) Lam, is a wild herb in the Rubiaceae family and is also an annual plant that can be erect or prostrate and is sparsely branched. It is widely distributed throughout the tropical regions of America, Africa, Asia, and the islands of the western Pacific [1]. It is a popular homeopathic medicine in India, China, and Africa and is harvested from the wild for local use as food, medicine, and a natural dye. The whole plant extract contains high levels of antioxidant activity due to secondary compounds such as phenolics and flavonoids [2,3], which are known for their anti-inflammatory, antibacterial, antioxidant, and anti-cancer properties [4-7].

The sustainable, high-yielding number of secondary compounds is the utmost goal in the herb industry. Various technologies are applied to pursue it, such as tissue and cell culture, precursor feeding, and elicitation treatments [8]. The treatments, such as using methyl jasmonate (elicitors), sugar (induction of osmosis), polyethylene glycol (PEG) (drought stress) on cell suspension, and shoot clusters in vitro, were applied to increase the contents of secondary compounds in H. corymbosa (L.) Lam [9-11]. Recently, genome editing technology using CRISPR/Cas9 edits is being introduced to boost the production of secondary metabolites [12]. However, there are a few challenges with these technologies, such as difficulties in large-scale implementation, the limitation of technology accessibility, and poor the social acceptance of gene-edited plants $[13,14]$. Herb producers are continuing 
to explore more reliable and sustainable technologies to increase the yield of secondary metabolites without genetic manipulation and chemical intervention.

Light is essential for the phytochemical synthesis and the accumulation of secondary metabolite compounds in plants [15-18]. LED lights have narrow bandwidths, produce less heat, and are a convenient integration into electronic systems. LED lights are applicable for plant light experimentations to study the influence of light in photosynthetic performance, plant growth, and physiological reactions [19]. In the visible light spectra, blue and red light energy was demonstrated as having a more significant effect than other photosynthetically active radiation (PAR) wavelengths [20,21]. Changes in LED wavelengths and light intensity can shift the primary and secondary metabolism in plants, alter the plant's metabolism, and effect the accumulation of the plant's functional products [16]. Several studies have shown that applying LED lights in the right spectrum in plant cultivation can increase the total amount of phenolic compounds and flavonoids in plants [17,18].

The goal of this study was to investigate the efficiency of H. corymbosa (L.) Lam production under blue $450 \mathrm{~nm}$ and red $660 \mathrm{~nm}$ LED lights for overall plant growth, photosynthetic characteristics, and the contents of some key secondary metabolites.

\section{Results}

The experiments of $H$. corymbosa (L.) Lam were conducted under three different light conditions: monochromatic red LED $660 \mathrm{~nm}(\mathrm{R})$, blue LED $450 \mathrm{~nm}(\mathrm{~B})$, and a fluorescent lamp (FL). Table 1 shows that the blue LED light caused the largest reduction in the total leaf area, followed by the red LED light and FL. The blue LED light had the highest effect on stomatal aperture, Hill reaction activity, and respiratory rate comparatively, but no different effects were detected between the red LED light and FL (Table 1). In general, various studies demonstrated that both blue and red LED lights contributed to enhanced plant growth [22-24], but our study showed the blue LED light was more effective than the red LED light for H. corymbosa (L.) Lam.

Table 1. The leaf area, stomatal aperture, Hill reaction activity, and respiratory rate of $H$. corymbosa (L.) Lam leaves after 4 weeks of being grown under different light sources at $100 \mu \mathrm{mol} \cdot \mathrm{m}^{-2} \cdot \mathrm{s}^{-1}$ light intensity.

\begin{tabular}{ccccc}
\hline Light Source & $\begin{array}{c}\text { Leaf Area } \\
\left(\mathbf{( m}^{\mathbf{2}}\right)\end{array}$ & $\begin{array}{c}\text { Stomatal } \\
\text { Aperture } \\
(\boldsymbol{\mu m})\end{array}$ & $\begin{array}{c}\text { Hill Reaction Activity } \\
\mathbf{( n m o l ~ D C I P . M i l l i o n ~ o f ~}_{\left.\mathbf{C h l o r o p l a s t ~}^{-1} \cdot \mathbf{m i n}^{-1}\right)}\end{array}$ & $\begin{array}{c}\text { Respiratory Rate } \\
(\boldsymbol{\mu m o l} \\
\mathbf{O}_{\mathbf{2}} \cdot \mathbf{c m}^{-\mathbf{2}} \cdot \mathbf{m i n}^{-\mathbf{1})}\end{array}$ \\
\hline $\begin{array}{c}\text { Fluorescent lamp } \\
\text { Blue LED }\end{array}$ & $1.64 \pm 0.08^{\mathrm{a}}$ & $3.30 \pm 0.08^{\mathrm{b}}$ & $0.087 \pm 0.001^{\mathrm{b}}$ & $0.145 \pm 0.02^{\mathrm{b}}$ \\
Red LED & $1.13 \pm 0.05^{\mathrm{c}}$ & $4.22 \pm 0.17^{\mathrm{a}}$ & $0.108 \pm 0.002^{\mathrm{a}}$ & $0.219 \pm 0.02^{\mathrm{a}}$ \\
\hline
\end{tabular}

Means of \pm standard errors followed by different letters within columns are significantly different by Duncan's multiple range test with one-way ANOVA; $n=6$.

The values of $\mathrm{F}_{\mathrm{v}} / \mathrm{F}_{\mathrm{m}}, \mathrm{qP}$, and ETR of the H. corymbosa (L.) Lam under the blue LED light were significantly higher $(p \leq 0.05)$ than those under the red LED light, while the value of qN under the red LED light was higher (Table 2). Notably, the value of ETR under the blue LED light was almost threefold higher than that under the red LED light. This result aligned with the research by Miao et al. (2016), which proved that the blue LED light is more effective in ETR compared to the red LED light [25]. The contents of three types of pigments (chlorophyll a, chlorophyll b, and carotenoid) were measured to investigate how each pigment responds to different light sources (Table 3). There was no significant difference found in the content of chlorophyll a under three different light sources. However, the blue LED light decreased the content of chlorophyll $b$, while the red LED light decreased the content of carotenoid. Consequently, the $\mathrm{a} / \mathrm{b}$ ratio and the $(\mathrm{a}+$ b)/c ratio were different depending on the light sources, which suggests that optimal LED light sources could be selected for plant cultivation. 
Table 2. The maximal quantum yield of PSII $\left(\mathrm{F}_{\mathrm{v}} / \mathrm{F}_{\mathrm{m}}\right)$, photochemical fluorescence quenching coefficient, non-photochemical fluorescence quenching coefficient, and electron transfer rate of $H$. corymbosa (L.) Lam leaves after 4 weeks of growth under different light sources at $100 \mu \mathrm{mol} \cdot \mathrm{m}^{-2} \cdot \mathrm{s}^{-1}$ light intensity.

\begin{tabular}{|c|c|c|c|c|}
\hline Light Source & $F_{v} / F_{m}$ & $\mathrm{qP}$ & qN & $\begin{array}{c}\text { ETR } \\
\left(\mu \mathrm{mol} \text { Electron } \cdot \mathrm{m}^{-2} \cdot \mathrm{s}^{-1}\right)\end{array}$ \\
\hline Blue LED & $0.70 \pm 0.01$ & $0.87 \pm 0.02$ & $0.20 \pm 0.02$ & $24.48 \pm 0.53$ \\
\hline Red LED & $0.58 \pm 0.02 *$ & $0.45 \pm 0.04^{*}$ & $0.38 \pm 0.02 *$ & $9.15 \pm 0.43^{*}$ \\
\hline
\end{tabular}

Table 3. The pigments content in leaves of H. corymbosa (L.) Lam after 4 weeks of growth under different light sources at $100 \mu \mathrm{mol} \cdot \mathrm{m}^{-2} \cdot \mathrm{s}^{-1}$ light intensity.

\begin{tabular}{cccccc}
\hline \multirow{2}{*}{ Light Source } & \multicolumn{3}{c}{ Pigment Content $\left(\mathbf{m g} / \mathbf{g}_{\mathbf{F W}}\right)$} & \multirow{2}{*}{ a/b Ratio } & \multirow{2}{*}{$(\mathbf{a}+\mathbf{b}) / \mathbf{c}$ Ratio } \\
\cline { 2 - 4 } & Chlorophyll a & Chlorophyll b & Carotenoid & & \\
\hline Fluorescent lamp & $2.05 \pm 0.09^{\mathrm{a}}$ & $0.54 \pm 0.03^{\mathrm{a}}$ & $0.74 \pm 0.03^{\mathrm{a}}$ & $3.77 \pm 0.03^{\mathrm{b}}$ & $3.56 \pm 0.03^{\mathrm{b}}$ \\
Blue LED & $2.04 \pm 0.02^{\mathrm{a}}$ & $0.48 \pm 0.01^{\mathrm{b}}$ & $0.74 \pm 0.02^{\mathrm{a}}$ & $4.25 \pm 0.02^{\mathrm{a}}$ & $3.47 \pm 0.08^{\mathrm{b}}$ \\
Red LED & $2.09 \pm 0.05^{\mathrm{a}}$ & $0.57 \pm 0.02^{\mathrm{a}}$ & $0.68 \pm 0.01^{\mathrm{b}}$ & $3.70 \pm 0.03^{\mathrm{b}}$ & $3.93 \pm 0.11^{\mathrm{a}}$ \\
\hline
\end{tabular}

Means of \pm standard errors followed by different letters within columns were significantly different according to Duncan's multiple range test with one-way ANOVA; $n=6$.

Biomass was also measured in different light sources (Table 4). Compared to the control, the blue LED light increased the fresh weight of $H$. corymbosa (L.) Lam, while the red LED light reduced the fresh weight of $H$. corymbosa (L.) Lam. However, only the blue LED light increased the dry weight, and there was no dry weight difference measured between the red LED light and FL. In conclusion, the blue LED light was only effective in increasing both fresh and dry weight. Most studies demonstrated both blue and red LED lights contributing to enhanced overall plant biomass [26-28]; however, it was not applicable for H. corymbosa (L.) Lam.

Table 4. Fresh and dry weight of $H$. corymbosa (L.) Lam plants after 4 weeks of being grown under different light sources at the same light intensity at $100 \mu \mathrm{mol} \cdot \mathrm{m}^{-2} \cdot \mathrm{s}^{-1}$.

\begin{tabular}{ccc}
\hline Light Source & $\begin{array}{c}\text { Fresh Weight } \\
(\mathbf{g})\end{array}$ & $\begin{array}{c}\text { Dry Weight } \\
\text { (g) }\end{array}$ \\
\hline Fluorescent lamp & $21.13 \pm 0.33^{\mathrm{b}}$ & $1.67 \pm 0.08^{\mathrm{b}}$ \\
Blue LED & $24.89 \pm 1.51^{\mathrm{a}}$ & $2.07 \pm 0.13^{\mathrm{a}}$ \\
Red LED & $18.36 \pm 0.15^{\mathrm{c}}$ & $1.69 \pm 0.05^{\mathrm{b}}$ \\
\hline
\end{tabular}

Means of \pm standard errors followed by different letters within columns were significantly different according to Duncan's multiple range test with one-way ANOVA; $n=6$

Table 5 demonstrated the difference in metabolite production under different light sources. Four compounds were measured: sucrose, starch, total phenolic compounds, and total flavonoid. In both blue and red LED lights, sucrose contents decreased while starch content was increased under the blue LED light. In total phenolic compounds, both blue and red LED lights were effective in production, and the red LED light doubled the amount of the total phenolic compounds compared to the control. The blue LED light was effective in total flavonoid production, but there was no difference measured between the red LED light and control. Therefore, the blue LED light was more effective in the production of sucrose, starch, total phenolic compounds, and total flavonoid (Table 5). 
Table 5. Sucrose, starch, total phenolic content, and total flavonoid content of H. corymbosa (L.) Lam leaves after 4 weeks of being grown under different light sources at the same light intensity of 100 $\mu \mathrm{mol} \cdot \mathrm{m}^{-2} \cdot \mathrm{s}^{-1}$.

\begin{tabular}{ccccc}
\hline \multirow{2}{*}{ Light Source } & \multicolumn{4}{c}{ Content $\left(\mathbf{m g} / \mathbf{g}_{\mathbf{F W}}\right)$} \\
\cline { 2 - 5 } & Sucrose & Starch & Total Phenolic & Total Flavonoid \\
\hline Fluorescent lamp & $25.85 \pm 3.64^{\mathrm{a}}$ & $80.01 \pm 5.45^{\mathrm{b}}$ & $1.56 \pm 0.07^{\mathrm{c}}$ & $0.68 \pm 0.06^{\mathrm{b}}$ \\
Blue LED & $18.38 \pm 1.08^{\mathrm{b}}$ & $101.31 \pm 6.56^{\mathrm{a}}$ & $1.90 \pm 0.08^{\mathrm{b}}$ & $1.48 \pm 0.30^{\mathrm{a}}$ \\
Red LED & $17.69 \pm 1.45^{\mathrm{b}}$ & $78.04 \pm 8.20^{\mathrm{b}}$ & $3.50 \pm 0.16^{\mathrm{a}}$ & $0.58 \pm 0.08^{\mathrm{b}}$ \\
\hline
\end{tabular}

Means of \pm standard errors followed by different letters within columns were significantly different by Duncan's multiple range test with one-way ANOVA; $n=6$.

\section{Discussion}

Sucrose, as the product of photosynthesis through the Calvin cycle, is the main organic source [29]. It could be stored as starch, transported to be used for metabolism, or be used for respiration to generate the energy source ATP. The stored starch is responsible for biomass, although starch could be converted to sucrose [30,31]. Respiration produces ATP as an energy source to synthesize phenolic and flavonoid compounds [29,32]. Therefore, increasing plant biomass and the total amount of metabolite compounds is important for plant cultivation, especially for $H$. corymbosa (L.) Lam, which is used as a health supplement in various applications. This study demonstrated that the most effective light source to make total phenolic and flavonoid compounds is the blue LED light, although the conversion ratio of sucrose/starch and metabolic compounds in H. corymbosa (L.) Lam from different light sources is not known. Further study to explain the detailed mechanism of conversion from a photosynthesis product to phenolics and flavonoids is needed.

The decrease of sucrose in LED light treatment was correlated with an increase of total phenolic content in leaves of $H$. corymbosa (L.) Lam ex vitro plants. According to Darko et al. [16], light not only changes the quality of photosynthesis products but also affects secondary metabolism. The same trend was recorded in Brassica napus L., Lactuca sativa, Ocimum basilicum, and Rhodiola imbricata when the plants were exposed under red or blue LED with light intensity from 50 to $200 \mu \mathrm{mol} \cdot \mathrm{m}^{-2} \cdot \mathrm{s}^{-1}$ [15,33-35]. Previous studies have shown that total phenolic compound was increased with additional monochromatic LED light, even though the blue or red LED has been applied only as supplemental light or combine with another light source $[17,18]$. Several studies have reported the relationship between red or blue LED and phenylalanine ammonia-lyase (PAL), which is the key enzyme in the phenolic metabolic pathway [36-38].

\section{Materials and Methods}

\subsection{Plant Material and Growth Conditions}

For the in vitro experiment, 10-day-old H. corymbosa (L.) Lam plants grown from seeds on MS medium with $30 \mathrm{~g} / \mathrm{L}$ of sugar were used. The $\mathrm{pH}$ of the medium was adjusted to 5.8 before gelling the medium with $6 \mathrm{~g} / \mathrm{L}$ of agar. The culture conditions were controlled at $27 \pm 2{ }^{\circ} \mathrm{C}$ with a relative humidity of $65 \pm 5 \%, 50 \mu \mathrm{mol} \cdot \mathrm{m}^{-2} \cdot \mathrm{s}^{-1}$ using a fluorescent lamp with a 12 hours of light and 12 hours of dark (12/12) photoperiod. For ex vitro treatments, plants with two pairs of true leaves were grown from a seed on clean soil and cow manure (ratio 3:1) in a greenhouse under $450 \pm 100 \mu \mathrm{mol} \cdot \mathrm{m}^{-2} \cdot \mathrm{s}^{-1}$ sunlight at $32 \pm 2{ }^{\circ} \mathrm{C}$ with a relative humidity of $70 \pm 5 \%$.

\subsection{Light Treatment}

LED light tubes were provided by the LED Agri-Bio Fusion Technology Research Center (LAFTRC) at Chonbuk National University in the Republic of Korea. The experiments were conducted in three treatments: monochromatic red LED $660 \mathrm{~nm}(\mathrm{R})$, blue LED $450 \mathrm{~nm}$ (B), and a fluorescent lamp (FL) (Philips, The Netherlands) as a control. The 
emission spectra from light sources were measured with an MK-350S (UPRtek, Taipei, Taiwan) (Figure 1).

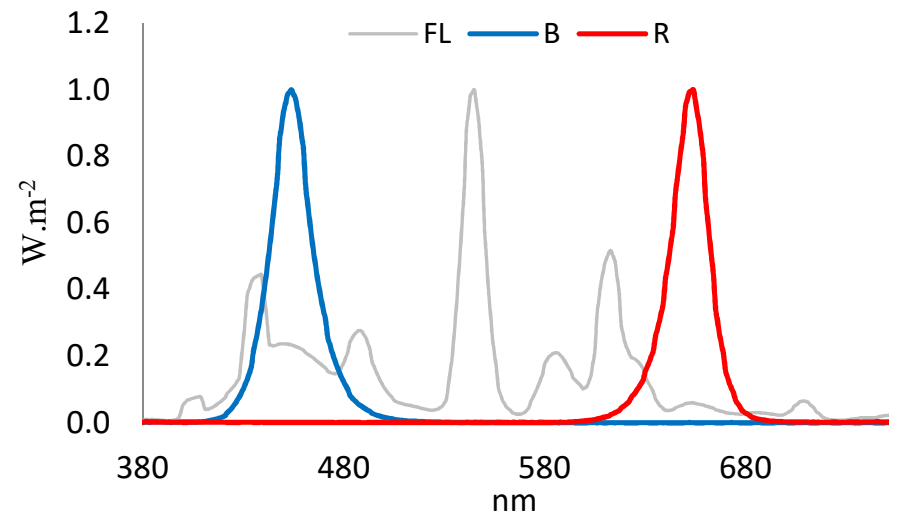

Figure 1. Spectral composition in different light treatments: blue (B), red (R) light-emitting diodes (LEDs), and fluorescent light (Fl). Peak wavelength numbers are shown for each broadband.

The in vitro and ex vitro plant materials were incubated for four weeks under light treatment with a $12 / 12$ photoperiod, and a light intensity was controlled at $100 \mu \mathrm{mol} \cdot \mathrm{m}^{-2} \cdot \mathrm{s}^{-1}$ and measured by a LI-250A with a LI-190R Quantum Sensor (LI-COR Inc., Lincoln, NE, USA) above the plant canopy.

\subsection{Measurements}

Measurements of the leaf area: Leaves were separated from plants, and the leaf area was determined by imaging (Canon IXUS 220HS, Monterey, CA, USA) and analysis using LIA for Win32 software. The area of a single leaf was calculated as the ratio of total leaf area to leaf number.

Measurements of stomatal aperture: The fifth leaves (from the top of the plants) were swept onto the underside with a cyanoacrylate glue (mixed in toluene and ethyl acetate solvents) and fixed on the slide. The surface of the leaf with the stomata was printed on the cyanoacrylate film [39]. The cyanoacrylate film was photographed by a CKX41 inverted microscope (Olympus, Tokyo, Japan) with a DFC450 camera (Leica, Wetzlar, Germany), and the stomatal aperture was measured by the ImageJ program (Wayne Rasband, imagej.net).

Isolation of chloroplasts and determination of the Hill reaction activity: The Hill reaction activity was assessed and described by Henselová et al. (2003), with slight modifications [40]. To isolate chloroplast, $0.5 \mathrm{~g}$ of mature leaves were ground in a mixture of $9 \mathrm{~mL}$ $\mathrm{NaCl} 0.35 \mathrm{M}$ and $1 \mathrm{~mL}$ Tris $50 \mathrm{mM}$ with a $\mathrm{pH}$ of 8 . The extract mixture was centrifuged at $500 \mathrm{rpm}$ (five minutes), and the supernatant was collected. The supernatant was further centrifuged for a second time at $2000 \mathrm{rpm}$ (five minutes), and the residue collected contained isolated chloroplasts. The manipulations were performed at $3-5{ }^{\circ} \mathrm{C}$ in the dark. The chloroplast density was determined using a Neurban erythrocyte counting chamber. Half a milliliter of chloroplast suspension that was isolated from the leaves determined the Hill reaction activity through the color loss of 2,6-dichlorophenol indophenol $0.25 \times 10^{-4} \mathrm{M}$ (DCIP) by optical density at $600 \mathrm{~nm}$ (GENESYSTM 30, Thermo Fisher Scientific Inc, Waltham, MA, USA) in the phosphate buffer, which consisted of $0.15 \mathrm{M} \mathrm{Na}_{2} \mathrm{HPO}_{4} \cdot 12 \mathrm{H}_{2} \mathrm{O}$ and $0.15 \mathrm{M}$ $\mathrm{KH}_{2} \mathrm{PO}_{4}(8: 2)(\mathrm{pH} 6.5)$ after 10 min of being exposed to growth light.

Measurements of net respiratory rate: The pair of the fifth leaves were isolated and measured using the gas exchange rate by an oxygen electrode with the LD2 electrode chamber of the Leaf Lab 2 system (Hansatech Instruments, Hansatech, United Kingdom). The leaf chamber temperature was controlled at $27 \pm 1^{\circ} \mathrm{C}$. The net respiratory rate of the sample, in dark conditions, was calculated on the basis of the amount of oxygen absorbed in the leaf chamber $\left(\mu \mathrm{mol} \mathrm{O} 2 \cdot \mathrm{m}^{-2} \cdot \mathrm{s}^{-1}\right)$. 
Measurements of chlorophyll fluorescence parameters: A PAM-2500 portable chlorophyll fluorometer (Heinz Walz GmbH, Effeltrich, Germany) was used for chlorophyll fluorescence parameter measurements of the H. corymbosa (L.) Lam leaves. Briefly, the fifth leaves were dark-adapted $15 \mathrm{~min}$ before the measurement was taken by using dark leaf clips DLC-8. The leaf sample recorded the minimum fluorescence $\left(\mathrm{F}_{\mathrm{o}}\right)$ under modulated light $\left(0.1 \mu \mathrm{mol} \cdot \mathrm{m}^{-2} \cdot \mathrm{s}^{-1}\right)$, and, subsequently, maximum fluorescence $\left(\mathrm{F}_{\mathrm{m}}\right)$ was determined by using a saturation pulse of red light $\left(5700 \mu \mathrm{mol} \cdot \mathrm{m}^{-2} \cdot \mathrm{s}^{-1}, 0.8 \mathrm{~s}\right.$ duration). The leaf was exposed to the treatment light for $10 \mathrm{~min}$, and then the maximum fluorescence value $\left(\mathrm{F}_{\mathrm{m}}{ }^{\prime}\right)$ after a saturation pulse of red light $\left(5700 \mu \mathrm{mol} \cdot \mathrm{m}^{-2} \cdot \mathrm{s}^{-1}, 0.8 \mathrm{~s}\right.$ duration $)$ and the minimum fluorescence value $\left(\mathrm{F}_{\mathrm{o}}{ }^{\prime}\right)$ in $5 \mathrm{~s}$ in far-red light were recorded. The parameters of chlorophyll fluorescence included maximal quantum yield of photosystem II $\left(\mathrm{F}_{\mathrm{v}} / \mathrm{F}_{\mathrm{m}}\right.$, from 0 to 1$)$, photochemical fluorescence quenching coefficient (qP), non-photochemical fluorescence quenching coefficient (qN), and relative electron transfer rate (ETR), which were measured and calculated automatically as follows [41].

The maximal quantum yield of photosystem II:

$$
\mathrm{Y}(\mathrm{II})=\mathrm{Fv} / \mathrm{Fm}=\frac{\mathrm{Fm}-\mathrm{Fo}}{\mathrm{Fm}}
$$

The photochemical fluorescence quenching coefficient:

$$
\mathrm{qP}=\frac{\mathrm{Fm}^{\prime}-\mathrm{F}}{\mathrm{Fm}^{\prime}-\mathrm{Fo}^{\prime}}
$$

The non-photochemical fluorescence quenching coefficient:

$$
\mathrm{qN}=1-\frac{\mathrm{Fm}^{\prime}-\mathrm{Fo}^{\prime}}{\mathrm{Fm}-\mathrm{Fo}^{\prime}}
$$

The electron transfer rate:

$$
\mathrm{ETR}=\mathrm{PAR} \times \mathrm{ETR}_{\mathrm{Factor}} \times \mathrm{P}_{\mathrm{PS} 2} / \mathrm{P}_{\mathrm{PPS}} \times \mathrm{Y}(\mathrm{II})
$$

PAR was light intensity measured from treatment light. The ETR Factor value was 0.84 , and the $\mathrm{P}_{\mathrm{PS} 2} / \mathrm{P}_{\mathrm{PPS}}$ value was 0.5 .

Determination of fresh and dry weight: All leaves were separated from the plant, and the fresh weight was determined by HR-202i balance (A\&D Company, Limited, Japan). For dry weight determination, the leaves were dried in an electric drying oven (UNB 500, Memmert, Germany) at $60^{\circ} \mathrm{C}$ for three days until a constant mass was achieved.

\subsection{Compound Extraction}

Extract and determine total sugar and starch content: The fresh leaf samples were ground in absolute ethanol, centrifuged, and the supernatant (supernatant 1) was collected. The residue was hydrolyzed by perchloric acid, centrifuged, and the supernatant (supernatant 2) was also collected. The optical density of the mixture of the two supernatants (separately) with phenol and sulfuric acid was measured. The extraction and determination of total sugar and starch content were based on the description of Coombs et al. [42].

Extract and estimate total phenolic and flavonoid: Total phenolic and flavonoid extraction was carried out using the method of Victório et al. (2009) [43]. Briefly, a sample of $1 \mathrm{~g}$ of dry leaves was extracted with $20 \mathrm{~mL}$ of ethanol $70 \%$, and the microwave method was used (Panasonics, auto sensor diet, full power) at $60^{\circ} \mathrm{C}$ and filtered through $0.45 \mu \mathrm{m}$ filter paper. The total phenolic in the leaves was estimated by the Folin-Ciocalteu method according to the principle of the reduction of the Folin-Ciocalteu reagent by the phenol compound in an alkaline medium and the resulting color product. The phenolic content was calculated as gallic acid equivalents (GAE) per gram of fresh weight leaves by optical density at $765 \mathrm{~nm}$ and the gallic acid calibration curve. The total flavonoid content was 
determined by the aluminum chloride colorimetric method. The total flavonoid content was calculated as rutin equivalents (RE) per gram by optical density at $510 \mathrm{~nm}$ and the rutin calibration curve [44].

\subsection{Statistical Analysis}

All experiments have six replications per treatment. The data recorded from the experiments were statistically processed using SPSS 11.5 for Windows. Statistical significance was estimated at $p<0.05$ according to $t$-test and Duncan's multiple range test with one-way ANOVA. All data were given as mean \pm SE.

\section{Conclusions}

Plants can make a lot of valuable chemical compounds from various metabolic processes. Those compounds were collected by growing plants and harvesting the target organs that contain them. With advent of new technology, scientists use genetic approaches to increase the target product by manipulating genes. However, these methods can be controversial. However, in the current study, the different photosynthesis parameters of H. corymbosa (L.) Lam under monochromatic blue or red LED light was investigated. A total of $450 \mathrm{~nm}$ blue LED promoted photosynthesis in leaves through an increased stomatal aperture; the mechanisms to protect the photosynthetic apparatus were maintaining the carotenoid content and increasing the appearance of starch in leaves. Along with this, blue LED light increased the respiratory rate, thus leading to the greater biomass of plants. In contrast, the plants that were exposed long term under red LED light $(660 \mathrm{~nm})$ treatment showed the "red light syndrome" specifically symptom with the lower biomass of plants. Both monochromatic LED lights play an important role in controlling the distribution of photosynthetic products in secondary compound metabolism such as total phenolic and total flavonoids in leaves of $H$. corymbosa (L.) Lam. Understanding how plants respond to different light sources makes it possible to control the growth and accumulation of desired bioactive compounds in plants.

Author Contributions: A.T.L. contributed to conducting the experiments; A.T.L. processed the data and writing the manuscript; J.-K.Y. and G.-D.H. reviewed the manuscript; T.K.D. and Y.-S.C. contributed to discuss the experimental results and edited the manuscript. All authors have read and agreed to the published version of the manuscript.

Funding: This research was funded by National Research Foundation of Korea (NRF) grant funded by the Ministry of Education (2019R1A6A1A11052070).

Data Availability Statement: The data presented in this study are available on request from the corresponding author. The data are not publicly available due to privacy.

Acknowledgments: We are grateful to the Research Center for High-Tech Application in Agriculture (RCHAA), University of Sciences, Vietnam.

Conflicts of Interest: The authors declare no conflict of interest.

\section{References}

1. Lewis, W.H. Oldenlandia corymbosa (rubiaceae). Grana Palynol. 1964, 5, 330-341. [CrossRef]

2. Sasikumar, J.M.; Maheshu, V.; Aseervatham, G.S.B.; Darsini, D.T.P. In vitro antioxidant activity of Hedyotis corymbosa (L.) Lam. aerial parts. Indian J. Biochem. Biophys. 2010, 47, 49-52. [PubMed]

3. Yadav, R.; Agarwala, M. Phytochemical analysis of some medicinal plants. J. Phytol. 2011, 3, 10-14. [CrossRef]

4. Gupta, R.K.; Singh, R.K.; Swain, S.R.; Hussain, T.; Rao, C.V. Anti-hepatotoxic potential of Hedyotis corymbosa against Dgalactosamine-induced hepatopathy in experimental rodents. Asian Pac. J. Trop. Biomed. 2012, 2, 1542-1547. [CrossRef]

5. Sultana, T.; Rashid, M.A.; Ali, M.A.; Mahmood, S.F. Hepatoprotective and antibacterial activity of ursolic acid extracted from Hedyotis corymbos (L.). Bangladesh J. Sci. Ind. Res. 2010, 45, 27-34. [CrossRef]

6. Andriyani, R.; Risdian, C.; Udin, Z. Cytotoxicity assay from fractions of hedyotis corymbosa extract against breast cancer cell line T47D. Indones. J. Cancer Chemoprev. 2011, 2, 182. [CrossRef]

7. Endrini, S. Antioxidant activity and anticarcinogenic properties of "rumput mutiara" $\{$ Hedyotis corymbosa (L.) Lam. $\}$ and "pohpohan" (Pilea trinervia (Roxb.) Wight\}. J. Med. Plants Res. 2011, 5, 3715-3718. 
8. Sharma, S.; Sharma, S.; Kukreja, S.; Jadon, V.S.; Sharma, V. Plant tissue culture methods in secondary metabolite production-A mini review. Plant Cell Biotechnol. Mol. Biol. 2020, 21, 144-153.

9. Chia, T.F.; Hew, C.S.; Lee, Y.K. Cell suspension culture of Hedyotis spp. Bot. Gaz. 1988, 149, 376-381. [CrossRef]

10. Norrizah, J.S.; Suhaimi, M.Y.; Rohaya, A.; Roslan, N.N. Ursolic acid and oleanolic acid productions in elicited cell suspension culltures of Hedyotis corymbosa. Biotechnology 2012, 11, 238-242. [CrossRef]

11. Le, A.T.; Hoang, T.T.T.; Phan, N.H. Development of shoots of Hedyotis corymbosa (L.) Lam. In Vitro Culture 2015, 5, 75-84. [CrossRef]

12. Sabzehzari, M.; Zeinali, M.; Naghavi, M.R. CRISPR-based metabolic editing: Next-generation metabolic engineering in plants. Gene 2020, 759, 144993. [CrossRef]

13. Mitsunobu, H.; Teramoto, J.; Nishida, K.; Kondo, A. Beyond native Cas9: Manipulating genomic information and function. Trends Biotechnol. 2017, 35, 983-996. [CrossRef]

14. Soyars, C.L.; Peterson, B.A.; Burr, C.A.; Nimchuk, Z.L. Cutting edge genetics: Crispr/cas9 editing of plant genomes. Plant Cell Physiol. 2018, 59, 1608-1620. [CrossRef]

15. Bantis, F.; Ouzounis, T.; Radoglou, K. Artificial LED lighting enhances growth characteristics and total phenolic content of Ocimum basilicum, but variably affects transplant success. Sci. Hortic. 2016, 198, 277-283. [CrossRef]

16. Darko, E.; Heydarizadeh, P.; Schoefs, B.; Sabzalian, M.R. Photosynthesis under artificial light: The shift in primary and secondary metabolism. Philos. Trans. R. Soc. B Biol. Sci. 2014, 369, 20130243. [CrossRef]

17. Jung, W.S.; Chung, I.M.; Hwang, M.H.; Kim, S.H.; Yu, C.Y.; Ghimire, B.K. Application of light-emitting diodes for improving the nutritional quality and bioactive compound levels of some crops and medicinal plants. Molecules 2021, 26, 1477. [CrossRef]

18. Hasan, M.M.; Bashir, T.; Ghosh, R.; Lee, S.K.; Bae, H. An overview of LEDs' effects on the production of bioactive compounds and crop quality. Molecules 2017, 22, 1420. [CrossRef] [PubMed]

19. Viršile, A.; Brazaityte, A.; Sirtautas, R.; Duchovskis, P. Light spectral effects on phenolic compounds in Perilla frutescens leaves as related to the leaf age, color and duration of exposure. Acta Hortic. 2017, 1170, 981-988. [CrossRef]

20. Dou, H.; Niu, G.; Gu, M.; Masabni, J.G. Effects of light quality on growth and phytonutrient accumulation of herbs under controlled environments. Horticulturae 2017, 3, 36. [CrossRef]

21. Manukyan, A. Effects of PAR and UV-B radiation on herbal yield, bioactive compounds and their antioxidant capacity of some medicinal plants under controlled environmental conditions. Photochem. Photobiol. 2013, 89, 406-414. [CrossRef] [PubMed]

22. Liu, J.; van Iersel, M.W. Photosynthetic physiology of blue, green, and red light: Light intensity effects and underlying mechanisms. Front. Plant Sci. 2021, 12, 619987. [CrossRef]

23. Lobiuc, A.; Vasilache, V.; Pintilie, O.; Stoleru, T.; Burducea, M.; Oroian, M.; Zamfirache, M.M. Blue and red LED illumination improves growth and bioactive compounds contents in acyanic and cyanic Ocimum basilicum L. Microgreens. Molecules 2017, 22, 2111. [CrossRef]

24. Kong, Y.; Nemali, K. Blue and far-red light affect area and number of individual leaves to influence vegetative growth and pigment synthesis in lettuce. Front. Plant Sci. 2021, 12, 667407. [CrossRef] [PubMed]

25. Miao, Y.X.; Wang, X.Z.; Gao, L.H.; Chen, Q.Y.; Mei, Q.U. Blue light is more essential than red light for maintaining the activities of photosystem II and I and photosynthetic electron transport capacity in cucumber leaves. J. Integr. Agric. 2016, 15, 87-100. [CrossRef]

26. Hung, C.D.; Hong, C.H.; Kim, S.K.; Lee, K.H.; Park, J.Y.; Nam, M.W.; Choi, D.H.; Lee, H.I. LED light for in vitro and ex vitro efficient growth of economically important highbush blueberry (Vaccinium corymbosum L.). Acta Physiol. Plant. 2016, $38,152$. [CrossRef]

27. Lee, M.J.; Son, K.H.; Oh, M.M. Increase in biomass and bioactive compounds in lettuce under various ratios of red to far-red LED light supplemented with blue LED light. Hortic. Environ. Biotechnol. 2016, 57, 139-147. [CrossRef]

28. Maluta, F.A.; Bordignon, S.R.; Rossi, M.L.; Ambrosano, G.M.B.; Rodrigues, P.H.V. In vitro culture of sugarcane exposed to different light sources. Pesqui. Agropecu. Bras. 2013, 48, 1303-1307. [CrossRef]

29. Patrick, J.W.; Botha, F.C.; Birch, R.G. Metabolic engineering of sugars and simple sugar derivatives in plants. Plant Biotechnol. J. 2013, 11, 142-156. [CrossRef] [PubMed]

30. Tiessen, A.; Padilla-Chacon, D. Subcellular compartmentation of sugar signaling: Links among carbon cellular status, route of sucrolysis, sink-source allocation, and metabolic partitioning. Front. Plant Sci. 2013, 3, 306. [CrossRef] [PubMed]

31. Fünfgeld, M.M.F.F.; Wang, W.; Ishihara, H.; Arrivault, S.; Feil, R.; Smith, A.M.; Stitt, M.; Lunn, J.E.; Niittylä, T.; Lunn, J.; et al. The pathway of starch synthesis in Arabidopsis thaliana leaves. bioRxiv 2021, 1-31. [CrossRef]

32. Sarkar, D.; Shetty, K. Metabolic stimulation of plant phenolics for food preservation and health. Annu. Rev. Food Sci. Technol. 2014, 5, 395-413. [CrossRef]

33. Johkan, M.; Shoji, K.; Goto, F.; Hashida, S.; Yoshihara, T. Blue light-emitting diode light irradiation of seedlings improves seedling quality and growth after transplanting in red leaf lettuce. HortScience 2010, 45, 1809-1814. [CrossRef]

34. Kapoor, S.; Raghuvanshi, R.; Bhardwaj, P.; Sood, H.; Saxena, S.; Chaurasia, O.P. Influence of light quality on growth, secondary metabolites production and antioxidant activity in callus culture of Rhodiola imbricata Edgew. J. Photochem. Photobiol. B Biol. 2018, 183, 258-265. [CrossRef] [PubMed]

35. Park, C.H.; Kim, N.S.; Park, J.S.; Lee, S.Y.; Lee, J.W.; Park, S.U. Effects of light-emitting diodes on the accumulation of glucosinolates and phenolic compounds in sprouting canola (Brassica napus L.). Foods 2019, 8, 76. [CrossRef] 
36. Heo, J.-W.; Kang, D.-H.; Bang, H.-S.; Hong, S.-G.; Chun, C.-H.; Kang, K.-K. Early growth, pigmentation, protein content, and phenylalanine ammonia-lyase activity of red curled lettuces grown under different lighting conditions. Korean J. Hortic. Sci. Technol. 2012, 30, 6-12. [CrossRef]

37. Park, W.T.; Yeo, S.K.; Sathasivam, R.; Park, J.S.; Kim, J.K.; Park, S.U. Influence of light-emitting diodes on phenylpropanoid biosynthetic gene expression and phenylpropanoid accumulation in Agastache rugosa. Appl. Biol. Chem. 2020, 63, 25. [CrossRef]

38. Son, K.H.; Park, J.H.; Kim, D.; Oh, M.M. Leaf shape index, growth, and phytochemicals in two leaf lettuce cultivars grown under monochromatic light-emitting diodes. Korean J. Hortic. Sci. Technol. 2012, 31, 664-672. [CrossRef]

39. Beadle, C.L.; Ludlow, M.M.; Honeysett, J.L. Water relations. In Techniques in Bioproductivity and Photosynthesis; Coombs, J., Hall, D.O., Long, S.P., Eds.; Pergamon Press Ltd.: Oxford, UK, 1985; pp. 50-61.

40. Henselová, M.; Regecová, M.; Sováková, A. Isolation of chloroplasts in the Karwinskia species and determination of their photochemical activity under in vitro conditions. Plant Soil Environ. 2004, 50, 149-156. [CrossRef]

41. Baker, N.R. Chlorophyll fluorescence: A probe of photosynthesis in vivo. Annu. Rev. Plant Biol. 2008, 59, 89-113. [CrossRef] [PubMed]

42. Coombs, J.; Hind, G.; Leegood, R.C.; Tieszen, L.L.; Vonshak, A. Analytical techniques. In Techniques in Bioproductivity and Photosynthesis; Coombs, J., Hall, D.O., Long, S.P., Eds.; Pergamon Press Ltd.: Oxford, UK, 1985; pp. $219-228$.

43. Victório, C.P.; Lage, C.L.S.; Kuster, R.M. Flavonoid extraction from Alpinia zerumbet (Pers.) Burtt et Smith leaves using different techniques and solvents. Eclet. Quim. 2009, 34, 19-24. [CrossRef]

44. Baba, S.A.; Malik, S.A. Determination of total phenolic and flavonoid content, antimicrobial and antioxidant activity of a root extract of Arisaema jacquemontii Blume. J. Taibah Univ. Sci. 2015, 9, 449-454. [CrossRef] 